Digital Press Social Sciences and Humanities

Who Will Own This Site?: Managing Resources and Expectations on the Historical Site of Sekaran

Manggala Ismanto, Siti Zurinani, Andi Azmi and and Syahrul Hindarto

Proceeding of Indonesia Heritage Tourism Forum 2019 (IHTF 2019)

Dewi Pratika Ayu Dhira Pradati (eds) 


\title{
Who Will Own This Site?: Managing Resources and Expectations on the Historical Site of Sekaran
}

\author{
Manggala Ismanto*, Siti Zurinani, Andi Azmi, and Syahrul Hindarto \\ Anthropology Department, Brawijaya University, Malang, Indonesia \\ *e-mail: manggala@ub.ac.id
}

\begin{abstract}
Managing cultural heritage is a challenge for stakeholders. To manage a site, collaboration from various actors is needed to ensure the perspectives of each party can be conveyed, heard, and accommodated. The discovery of a new historical site called Sekaran in Sekarpuro Village, Malang Regency which has high cultural and historical values is a momentum to explore the relationship and negotiation of interests between cultural heritage management authorities and the local community. To see this phenomenon, researchers used the concept of "inclusive heritage discourse" (Kisić, 2013). This approach provides a discourse alternative to the management of cultural heritage, better known as authorization-based management, both by state and expert. Through IHD disharmony (dissonance) present from various actors is considered and understood as the entrance to negotiations to produce a framework for managing cultural heritage in a participatory manner. This study uses a qualitative approach with ethnographic methods. Qualitative research includes a collection process that varies from empirical material, including case studies, personal experience, life stories, interviews, texts, observation, and visual texts (Denzin \& Lincoln, 2005). In qualitative research, researchers are expected to interpret the phenomena faced to gain a deep understanding.
\end{abstract}

\section{Keywords}

actor, management of cultural heritage, participation, policy, Sekaran's site

\section{Introduction}

Managing cultural heritage is a challenge for stakeholders. To manage a site requires collaboration from a variety of actors to ensure the perspective of each party can be accommodated. Because of the important and strategic position of cultural heritage as one of the nation's identities, protection, management, and preservation must be carried out. The purpose of these activities is to advance national culture and for the prosperity of the people (Lembaran Negara Republik Indonesia Tahun 2010 Nomor 130, Tambahan Lembaran Negara Republik Indonesia Nomor 5168, 2010). In Malang, found a new site that has historical value around the beginning of March 2019. The site named Sekaran is located in Sekarpuro Village, Pakis District, Malang Regency.

Based on the results of the excavation and the interim findings of the East Java BPCB (Cultural Preservation Conservation Agency) team, the site located in the Pandaan-Malang toll road is a sacred building complex in the era before the Majapahit kingdom. Provisional estimates, this site was built during the kingdom of Singasari or Kediri, based on the findings of artifacts originating in the Song Dynasty that took place in the 10-14 century period (Werdiono, 2019a). In the excavation carried out for more than 10 days, BPCB gave recommendations to various related parties that the area must be protected and preserved. The results of the recommendations were submitted and agreed upon by the village, subdistrict, district, and also Jasa Marga. Jasa Marga, the party that built the toll road project, said it would create alternative lane scenarios such as fly-over so that the site area could be maintained (Werdiono, 2019c).

Efforts to manage this site must also be seen from the responses and perspectives of people who live in the area. To complete the understanding of the Sekaran Site, not only building structures must be examined, but also other archaeological objects that can provide the context of the times and the use site in the past. The problem that arises is that the artifacts on the site began to be hunted by residents when the site was first revealed to the public because the toll road project excavator opened a mound of land. Some artifacts found by local residents and residents outside the area such as gold coins, necklaces, earthenware jugs. 
Some people keep it as a private collection but some sell it to antique enthusiasts (Werdiono, 2019a). In order to retrieve the historical value artifacts, BPCB conducted socialization to the residents to return it to BPCB with a profit-changing model. The discovery of this site also gives hope to village governments who want to advance the economy of citizens. The Village Head has the intention to make this site an ancient tourist area and build a museum. It is hoped that Sekarpuro Village, which has been left behind, can benefit economically from managing the site (Hidayatullah, 2019).

The discovery of new cultural heritage sites with historical and cultural value in Malang Regency is quite important in developing cultural treasures, so it is necessary to map the issues that will arise and formulate an ideal form of management. The researcher will emphasize how the perspective originating from the authority (BPCB) and the perspective of the community are interconnected and negotiated. State authorities who have the legitimacy to regulate cultural heritage will prioritize conservation in terms of the material culture of the site and efforts to introduce the site as a cultural heritage area. On the other hand, there is a perspective from the community that views the region as part of daily life in the religious and economic sphere. This research will also explore the patterns of governance of cultural heritage sites that will emerge that are expected to be able to bridge differences in perspective, both from the authorities (BPCB) and from the local community.

The findings targeted in this study include: a) Description of the perspectives and interests of each actor, regarding Sekaran site; b) cultural heritage management patterns that integrate stakeholder interests in a participatory manner for the benefit of cultural values; c) involvement and participation of various actors in the community in influencing policies and planning on the management of the site. In addition, this research has contributed to the study of social science related to the management of cultural heritage sites. Participatory cultural heritage management is an ideal form to accommodate the interests and resources of the various actors involved. Through this research, the momentum of the discovery of the new site Sekaran in Malang is an entry point to see how various actors negotiate to determine site policy and management.

\section{Participation in Cultural Heritage Management}

The management of cultural heritage is now beginning to be seen through the perspective or approach of participation. In the world of cultural heritage management, Kisić (2013) through his book Governing Heritage Dissonance offers an alternative new perspective to overcome conflicts between the actors involved. The concept offered is 'inclusive heritage discourse' (IHD). This approach provides an alternative discourse on the management of cultural heritage which places more emphasis on authorization-based management, both by the state and expert. Through IHD the disharmony (dissonance) present from various actors is considered and understood as the entry point for negotiations to produce a framework for managing cultural heritage. From this point of view, the voice or opinion of other actors outside the authority to regulate cultural heritage is something that should be appreciated.

In this case, those who seek to introduce cultural heritage in a certain region must be willing to collaborate with other actors in the region, one of which is the local community. In this case, researchers and also observers of cultural heritage can apply research models by involving local communities (Johnston \& Marwood, 2017). This is based on the idea of the values contained in cultural preservation. If indeed cultural heritage is intended as cultural capital owned by the community, then the effort must start with joint social action (Harrison 2010 as cited in Johnston \& Marwood, 2017). When cultural heritage is labeled as public heritage, but public involvement in it has never arisen even monopolized by the authorities, the management is unable to listen to cultural aspirations that come from the community (Waterton 2015 as cited in Johnston \& Marwood, 2017).

The context and characteristics of resources inherent in cultural preservation must be understood before forming a management policy. Dexia \& Shuqiang (2014) in their research offering the idea that cultural heritage resources are considered as public resources. Because of this character of public property, its management cannot be solely left to the market mechanism. For this reason, a management model that is expected to be adequate to accommodate a variety of interests is to use network governance. Through this mechanism, it is expected to meet a variety of interests and also resources to manage a site. In line with this, Cheng, Li, \& Ma's (2014) research findings in Penang show that conservation in cultural heritage areas can be assisted by the community and involve a variety of voluntary actors. In Penang, this area has an area that has been designated by UNESCO as an international cultural heritage area which is located along the Strait of Malacca, which is the area of the city of Melaka and George Town. The cultural heritage in George 
Town is managed by a community organization, the Penang Heritage Trust which was established in 1986 involving architects, historians, communal landowners, and activists.

Efforts to bring cultural heritage management closer to the negotiations between authority and experts with the community began to emerge to gain new understanding related to the past cultural values. Through case studies in two regions that listened to the aspirations of local communities provided input for the management of cultural heritage areas. The desire of people who imagine that cultural heritage sites can lift the village economy into a foothold in managing certain cultural sites (McGill, 2018). Joint management of cultural heritage sites by looking at the perspective of local communities is one approach that has begun to be used to avoid conflicts of interest. Through studies in Australia, it appears that there are coordination and negotiation between archeologists and aboriginal communities in viewing cultural sites (Prangnell, Ross, \& Coghill, 2010).

The link between heritage and tourism can also be seen within the scope of conflicts of interest. Ferreira's study (2013) looks at how the determination of natural areas in Ilha Grande, Brazil, and their relation to the interests of local communities. In the eyes of preservation, there are efforts to freeze (freeze) time and social facts. The area which is a preservation area is considered to be sterile from community activities. While in reality, the area is also used by the community to survive related to land and natural resource management.

\section{Revealing the Sekaran Site}

The site nowadays known as the Sekaran site is located in the Sekaran Hamlet area, Sekarpuro, which was discovered after the construction of the Pandaan-Malang toll road. This infrastructure development began in 2017 with a completion target for construction in 2019. The main objective of development with a total cost of Rp 5,970 Trillion managed by the Ministry of Public Works and Public Housing (PUPR) is to improve connectivity in the East Java region. With this toll road, the distance from Surabaya to Malang, which usually takes 4-6 hours, can be reduced to 1 hour. This toll road has a total length of $38 \mathrm{~km}$ which is divided into 5 sections, namely: (1) Pandaan-Purwodadi, 15 km; (2) Purwodadi-Lawang, 8 km; (3) Lawang-Singosari, 7 km; (4) Singosari-Pakis, $4 \mathrm{~km}$; and (5) Pakis-Malang, $4 \mathrm{~km}$ (Anwar, 2019). The discovery of this site stems from the activities of toll road construction workers while digging the ground using an excavator. When this activity took place, accidentally discovered a brick rock structure

One of the parties who have contributed to ask for expert assistance in further investigating the historical value of the Sekaran site is the "Jelajah Jejak Malang" (JJM). One of its founders, Restu Respati, said that the effort made by JJM in collaboration with the Sekaran community was to invite competent experts to further study the findings. The team from JJM made a report which contained site findings and site characters sent to BPCB East Java so that there was a follow up to explore the site. "In addition to sending an official email to BPCB, we also contact directly via WhatsApp, and immediately responded that BPCB East Java will come soon," said Restu.

BPCB sent its team to carry out an excavation based on a report given by representatives of the community concerned about cultural heritage in Malang. BPCB carried out a five-day excavation that began on March 12, 2019, with students and academics from Malang State University (UM). From the results of the excavation, it was found that the brick structure that was found most likely came from the period before the Majapahit era, namely the Kingdom of Singosari or Kediri Kingdom. This is known from the comparison of brick sizes at the Sekaran Site with those at the Trowulan Site. From the findings, the size of bricks in Sekaran has a larger character (in centimeters), which is $38 \times 25 \times 8 ; 35 \times 2 \times 7$; and $32 \times 23 \times 6$. Whereas the bricks found at the Trowulan site have the largest size around 32x7x23 (Werdiono, 2019b).

The initial allegation of the construction period of this site is also supported by the discovery of some artifacts in the area. Artifacts found include coins, pottery, and ceramics dating from the Song Dynasty, around the 10th to 14 th centuries. On the other hand, the Majapahit era took place in the period 1293-1500 AD. The findings of this temporary coin lead to Singasari. Besides coins, porcelain was also found which was dominated by the Song Dynasty. The contemporaries in the 10th to 14th centuries, "said Wicaksono Dwi Nugroho, a researcher from BPCB East Java (Werdiono, 2019b).

The estimate is also supported by regional developments in the area of the Sekaran site which has a relationship with Majapahit, namely the Tunjungan and Kabalan areas. This was conveyed by UM Historian, Dwi Cahyono who said the eastern part of Malang was a governmental level of character, with a leader named after a Rakai, known as Rakai Tugaran. The composition of this governance structure emerged in the early era of the Mpu Sindok association, in the early 10th century. The Rehabilitation Area is located in 
the Amprong watershed in the valley on the west side of Mount Buring, close to the Sekaran Site. In addition, in the 14th century, near Sekarpuro Village there was also a subordinate kingdom called Kabalan led by Bhre Kabalan, another name for Kusumawardani, son of Hayam Wuruk (Raja Majapahit) (Werdiono, 2019b).

From preliminary research through this excavation BPCB has an initial hypothesis that the Sekaran Site is a pre-Majapahit holy building. From the structure, it is thought to be a cluster building made of bricks consisting of small complexes that form a larger complex. While in the middle of this site it is estimated as a sacred building that is supported by the existence of an altar-like structure and the foundation of the Paduraksa Archway as a place for people to enter and exit (Werdiono, 2019b).

The results of this research from BPCB provide recommendations that the Sekaran Site must be preserved. This was agreed by the village, subdistrict deliberations, and also the Office of Tourism and Culture of Malang Regency and Jasa Marga. With the excavation process from BPCB, the Pandaan-Malang toll road construction process had stopped. The General Manager of Engineering from PT Jasa Marga Pandaan-Malang said the site's findings did not affect toll development. He said Jasa Marga had made an alternative to shift the road to the east side to avoid the findings of the Sekaran Site. For further research, BPCB requested the Yogyakarta Archeology Center (Werdiono, 2019b).

Yogyakarta Archeology Center (Balai Arkeologi Yogyakarta) conducts research into the Sekaran Site to further explore the prospects and potential of the site. From the published report, Balar Yogyakarta provides several recommendations to relevant stakeholders, especially focusing on the field of research and conservation. To focus on the field of research, the recommendation offered is that the Archaeological Bureau of Yogyakarta was asked to conduct further research activities (explanation research) on the site by involving various scientific disciplines and longer research time. In terms of conservation, there are several stakeholders who were given recommendations, including the Culture and Tourism Bureau, which was suggested to arrange the Sekaran site development program in coordination with BPCB East Java. Then, to PT Jasa Marga Malang, to build a shelter for the Sekaran Site to prevent damage to the brick structure. Sekarpuro Village Government is also a party that has a big role in conservation activities through the security and development of the Sekaran Site. (Balai Arkeologi D.I Yogyakarta, 2019).

Several steps must be taken to propose a site to be a cultural heritage site. The first stage is the stage of the study conducted by the Cultural Heritage Expert Team (TACB). This TACB is required to conduct a study. There are two things done by the TACB namely assessing the status of cultural heritage and ranking. The two things that can be done simultaneously, related to ranking will be seen whether included in the CB ranking in the local, professional, or national domains.

TACB is formed directly by the regional head. If a region does not have a TACB, it must ask for assistance from a TACB that is above its level. For example, if Malang Regency does not have a team, while Malang has a team, Kab. Malang cannot ask for help from a team from Malang. The process that can be taken is to ask for help from the TACB at the Provincial level. Because it is independent and autonomous, it can be said that there is no direct relationship between TACB and BPCB or the Archaeological Center. But, the TACB can invite BPCB or the Archaeological Center as an additional team in charge of providing information and knowledge. So that the TACB has an independent nature because it is formed directly by the regional head. The next stage is the establishment of a cultural preservation site conducted by the head of the area where the object is located. In this process, the TACB Team will provide recommendations after the study is completed. Two SKs will appear after the study is completed and forwarded to the regional government, SK decree, and SK ranking. If there is a determination, it is already protected by law. After the next step is determined, register it nationally at the Ministry of Education and Culture online, which can be accessed by the public.

\section{Managing Expectations and Resources on the Sekaran's Site}

The discovery of the Sekaran historical site in Sekarpuro Village gives hope to improve the welfare of citizens. Seeing the condition of Sekarpuro Village, which is included in the underdeveloped village area, the Village Head has the intention to make this site an ancient tourist area. This area will be equipped with education-based public tourism with the establishment of a museum that contains a collection of artifacts found in the site environment. It is hoped that Sekarpuro Village, which has been left behind, can benefit economically from managing the site (Hidayatullah, 2019).

Before the idea of developing village tourism, the people of Sekarpuro Village formed an independent team to manage the existence of the Sekaran Site. This management is a spontaneous response carried out 
by residents when there is enough public attention to this site. The management is made to regulate the interest of visitors when the Site Now is a public concern at the beginning of this site found. This team was formed together with village government authorities through community consultations with representatives from several neighborhoods around the site. The site management was formed by the village head through deliberations at Pak Carik's house. In the meeting, Mr. Dudi and Mr. Joko were the main parts of the management, while the members were drawn from the people who did not have jobs in each RT in the Sekaran hamlet. For the heads of RT and RW, they have the role of being responsible for the members of their respective regions.

This independent management is formed by dividing tasks into teams. One of the teams formed was the management of visitor parking which was coordinated by Pak Dudi. The coordinator's duty is to monitor the attendance of the parking guard and the conditions around the site. To accommodate the various interests of the members of the parking guard, seven residents were selected from 5 RTs in Sekaran Hamlet. They set a schedule for taking turns guarding the parking every day and controlled by Pak Dudi. The next structure is the Secretary, who is assigned to Mr. Samsul. The task of the secretary is to record all forms of parking attendants and record financial income and expenses. Third, the treasurer assigned to Mr. Adin, who has the task of carrying or deviating all forms of finance in the Sekaran site management team. Another team formed was the security assigned to Pak Joko. The task of this team is to secure the condition of the Sekaran site area. In practice, almost every night this section of the site around the site carrying a flashlight to ensure site conditions are safe.

One of the main income from visitors to this site is parking management. When this site is crowded, it takes a party to maintain the safety of visitors' vehicles. This parking yield management sharing system is through a flat-sharing system for residents who take turns guarding parking. For the division of personnel guarding the site selected by each RT chairman, while for the arrangement of the daily guard schedule from Monday to. In one week if the personnel do not come or cannot be guarded then it cannot be replaced by other personnel, whereas if they do not come three times in a row then the name of the member will automatically be crossed out and removed from the management of the site. This agreement was agreed upon when forming the management of the Sekaran Site. As for the problem of sharing parking results on Sunday afternoon with the system divided equally.

But over time the management apparently reaped a problem. Initially, the appointment of people who do not have permanent jobs is expected to improve the economy and earn additional income from existing parking revenues. But over time it turned out that the community caused new problems for site management. The village head was disappointed because the main objective formed by the management turned into an arena to act like "little kings" in the community. For example, Pak Adin is actively looking for goods or artifacts in the toll road project area, so that he has a large collection. Over time, when the village asked to deposit his collection, Pak Adin refused firmly, the reason is that the search for these items was very difficult while the village provided unequal compensation. Finally, in order to solve this problem, the village head gave 100,000 rupiahs to Mr. Adin every time he lent his goods. Eventually, a split in this independent management was ended after less than two months.

The idea of planning an ancient tourist area is being launched by looking at the potential that is around the site. According to the presentation of the Head of Sekarpuro Village, this development will be realized in 2020. Facilities to be developed to support the integration of ancient tourism areas include building a tourist area which is located not far from the site. The location to be used in the development of this facility will be built on "bengkok" land owned by the Village Head.

To manage the expectations of this tourist area, the village government is faced with several challenges in the form of land management. After this site was discovered, until now there has not been any clarity on the status of the land for the development of the site area. The status of the land ownership of the existing site which is private land has been released by PUPR as a step in the toll road development procedure. After the site is found, PUPR then responds by providing space for site development. However, this is not accompanied by a transfer to related parties who have the authority to manage this site, such as the Regional Government of Malang Regency, or to the Village of Sekarpuro. "Though the village will be very prepared if the land is donated to the village," said the Village Head. On the other hand, the "bengkok" land which was planned to become a swimming pool area, according to information, also has not yet received compensation from the toll road construction.

According to Mr. Ahmad, the existence of the site is still under the authority of BPCB, East Java. So the village and Malang Regency Government can only wait further about the sustainability of the site's status. He also mentioned that until now the task of the village is only to secure the site by giving a fence around it. But according to him, the limit was not enough, because over time the condition of the land beside the site began to experience dredging by the toll road construction project, so the area of the site experienced 
shrinkage. With this, the village cannot do much, because the power of the site is not in the hands of the village or district. So that we can only wait for instructions from superiors namely Malang Regency Government or BPCB

In addition to the issue of land status, unclear authority in the management of the Sekaran site are also obstacles to the development of this area. But if it is not immediately handled by the PEMKAB then the site condition has no tourism potential that can attract tourists. Confusion arose in the local realm, especially in the Sekarpuro village government officials who questioned who had the authority and responsibility in managing the site. As stated by the village head of Sekarpuro, until now there has never been an invitation from the Malang Regency Tourism Office to discuss the future of the site. Until now, the village officials can only wait for the decision of the Malang Regency Government. Because of the unclear management of the site, the condition is poorly maintained and the roof that protects the site has begun to collapse.

\section{Conclusion}

The discovery of new historical sites allows us to see a variety of perspectives and expectations regarding the management of these sites. From these different interests and perspectives, it can actually be ammunition to gather ideas to move forward in making policy. With full of enthusiasm and hope, the community views that this site can raise the level of life of the surrounding community through communitybased management. This can be seen from the idea of spontaneous site land management to accommodate visitors' curiosity and the idea of building a community museum. Cultural heritage activists imagine that this area needs to be developed because it has historical and cultural values so that the site should not be eroded by toll road construction. On the other hand, in terms of authority to make this site a strong position, there must be a formal legal effort put forward by the district government to submit a decree on cultural heritage.

This is what is meant by Kisić (2013) as an inclusive heritage dissonance, as an effort to map out the problems of each actor who has an interest regarding the existence of the site (Kisić, 2013). This framework of thinking can be a productive solution if it is supported by a foundation of communication between related parties. However, in this case, each party spoke with its perspective without any representative space to establish strengths and practical solutions. In the absence of the space of communication, the inclusive management idea is increasingly buried. There is even a thought that because the cultural heritage regulatory regime is very much linked to the government, its management is highly dependent on the interests and concerns of the relevant authorities. The views of some of these parties see that state authority still has a large role in the management of cultural heritage, which is actually the participation of local communities and civil society has a large enough space. That way, there is an impasse in managing expectations and resources at the Sekaran Site because the communication space that wants to be knitted is never responded to by the competent authority.

Acknowledgments This research was supported by research grant funding provided by the Institute of Research and Community Service (ICRS) Brawijaya University.

\section{References}

Anwar, M. C. (2019). Tol Pandaan-Malang Diresmikan, Berikut Fakta \& Penampakannya. Retrieved from CNBC Indonesia website: https://www.cnbcindonesia.com/news/20190411092928-4-65916/tol-pandaanmalang-diresmikan-berikut-fakta-penampakannya

Balai Arkeologi D.I Yogyakarta. (2019). Executive Report Penelitian Penjajagan Situs Sekaran. Retrieved from https://arkeologijawa.kemdikbud.go.id/2019/04/18/executive-report-penelitian-penjajagan-situs-sekaran/).

Cheng, E. W., Li, A. H. F., \& Ma, S.-Y. (2014). Resistance, Engagement, and Heritage Conservation by Voluntary Sector: The Case of Penang in Malaysia. Modern Asian Studies, 48(3), 617-644. https://doi.org/10.1017/S0026749X1200087X

Denzin, N. K., \& Lincoln, Y. S. (2005). Introduction: The Dicipline and Practice of Qualitative Researc. In N. K. Denzin \& Y. S. Lincoln (Eds.), The Sage Handbook Of Qualitative Research Third Edition. California: 
Sage Publications.

Dexia, Z., \& Shuqiang, S. (2014). A Governance Framework of Chinese Heritage Resources Based on Social Network. Journal of Landscape Research 2014, 6(5-6), 7-8,13.

Ferreira, H. C. H. (2013). Tourism, nature and culture: Disputes for "heritage sites" in "participative debates" in ilha grande, state of rio de janeiro (rj), Brazil. Ambiente e Sociedade, 16(4), 63-80. https://doi.org/10.1590/S1414-753X2013000400005

Hidayatullah, M. R. E. (2019). Kades Sekarpuro Ingin Situs Sekaran jadi Lokasi Wisata untuk Tingkatkan Ekonomi Warga. Retrieved April 5, 2019, from Surya Malang website:

http://suryamalang.tribunnews.com/2019/03/19/kades-sekarpuro-ingin-situs-sekaran-jadi-lokasi-wisatauntuk-tingkatkan-ekonomi-warga

Johnston, R., \& Marwood, K. (2017). Action heritage: research, communities, social justice. International Journal of Heritage Studies, 23(9), 816-831. https://doi.org/10.1080/13527258.2017.1339111

Kisić, V. (2013). Governing Heritage Dissonance: Promises and Realities of Selected Cultural Policies. European Cultural Foundation.

Lembaran Negara Republik Indonesia Tahun 2010 Nomor 130, Tambahan Lembaran Negara Republik Indonesia Nomor 5168. , Undang-Undang Nomor 11 tahun 2010 tentang Cagar Budaya $§ ~(2010)$.

McGill, A. E. (2018). Learning from cultural engagements in community-based heritage scholarship. International Journal of Heritage Studies, 24(10), 1068-1083. https://doi.org/10.1080/13527258.2018.1475413

Prangnell, J., Ross, A., \& Coghill, B. (2010). Power relations and community involvement in landscape-based cultural heritage management practice: an Australian case study. International Journal of Heritage Studies, 16(1-2), 140-155. https://doi.org/10.1080/13527250903441838

Werdiono, D. (2019a). BPCB Eksavasi Situs Sekaran di Tol Pandaan-Malang. Retrieved April 2, 2019, from Kompas website: https://kompas.id/baca/utama/2019/03/12/bpcb-ekskavasi-situs-sekaran-di-tol-pandaanmalang/

Werdiono, D. (2019b). Sekaran, Situs Suci Pra Majapahit. Retrieved April 2, 2019, from Kompas website: https://kompas.id/baca/utama/2019/03/23/sekaran-situs-suci-pra-majapahit/

Werdiono, D. (2019c). Situs di Jalur Tol Pandaan-Malang Perlu Dilestarikan. Retrieved April 2, 2019, from Kompas website: https://kompas.id/baca/nusantara/2019/03/21/situs-di-jalur-tol-pandaan-malang-perludilestarikan/ 